\title{
Strength of Organizational Culture and Performance: Strategic Implications
}

\author{
Charles M. Byles \\ Oklahoma State University \\ Stillwater, Oklahoma \\ Robert J. Keating \\ University of North Carolina at Wilmington \\ Wilmington, North Carolina
}

In the last decade, the concept of a "strong culture" has been in vogue among academicians $([8],[23])$ and practitioners. Concerns about the increased complexity and turbulence in the macroenvironment and industry with its potential to increase costs or erode revenues have shifted attention toward the financial viability of wellentrenched values and beliefs (i.e., a "culture"). One line of thinking holds that such strong cultures are financially viable because they provide direction [8] and reduce the need for explicit control mechanisms such as extensive reports, policies, procedures, and direct supervision [23]. In addition, strong cultures provide pathways for executive and middle management decisions by capturing the essence of what has worked well in the past $([19],[23])$. Thus, with a reduction in the need for monitoring and guiding, executives are able to focus upon the creative task of developing new strategies or rethinking old ones. Similarly, middle managers can devote greater portions of time to increasing the efficiency or innovativeness of processes for which they are responsible.

However, despite these advantages, strong cultures made up of values and beliefs which fundamentally undermine the competitive advantage of the firm would be undesirable. For example, where a firm derives a distinct advantage from offering superior quality products; a widely held value of short-run profitability through cost containment will, in the long-run, undermine such an advantage. It seems logical that the viability of a strong culture depends on the extent to which it supports the competitive needs of the firm at a particular time. The research focus in this area ought to be directed at first exploring broadly the internal and external conditions for a firm which necessitate a strong or weak culture. A second step should delineate the sperific recommendations for particular kinds of firms and industries.

While much culture research to date has concentrated on content issues such as Martin and Siehl's [17] exposition of core values (such as respecting authority, fitting in, and being loyal) at General Motors and Barney's [3] "valuable, rare, and imperfectly imitable" cultures, others have paid more attention to cultural strength. Specifically, Peters and Waterman found that better performing companies had "a well defined set of guiding beliefs ..." ([23], p. 251). Similarly, Deal and Kennedy [8]

Journal of Business Strategies, Volume 6, Number 1 (Spring 1989) 
have argued that cohesive values in Japanese firms contribute significantly to their success.

The paper has three purposes. First, "culture" and "cultural strength" are defined. Sccond, the outcomes of strong cultures are discussed. Third, implications of culture for organization theory and strategy implementation are discussed. Finally, the relationships between cultural strength and strategy formulation are explored. Very generally, it is suggested that very strong cultures do not develop easily in all organizations and do not contribute to feelings of belongingness and satisfaction [8], and thus indirectly contribute to positive organizational performance through increased commitment. But at the macro level, a strong culture may discourage executives from making radical strategic changes in the face of new external opportunities and threats (such as GM's undue emphasis on profits and cost control without much concern for its effect on its many stockholders) [36]. Similarly, where organizational members have been encouraged to do things in a particular way, they can be expected to resist when required to make radical changes in response to a different strategic focus.

It seems then that the CEO's role is to develop a balance between the advantages and disadvantages of having a strong or weak culture. This balance is ultimately developed through considerations of the fit between culture, enviromment, and strategy.

\section{Definitions of Organizational Culture and Cultural Strength}

Organizational culture is commonly defined as a network of shared values, beliefs assumptions, or idcologies $([8],[19],\{20],[25],[26],[28],[33])$. Stories, symbols, rituals, and language systems are sometimes included in definitions of culture but will only be considered here as the more visible means by which culture is communicated. Culture provides the means by which organizational members interpret their social context and hence it governs the interaction of members with stakeholders and resources. As a result, culture has an indirect effect on the formulation of both strategic and administrative decisions. Culture can be distinguished from the similar concept "organization climate." Climate typically measures whether people's expectations in the organization are being met while culture is a reflection of the expectations themselves.

Some research on the content of culture identifies specific characteristics such "product quality emphasis", "profitability emphasis" [29] and "respect for the individual" [6]. Others, such as Barncy [3] are less specific, but conceptualize cultures as being "valuable", "rare", or "imperfectly imitable".

Besides the content of culture, the extent to which certain values and beliefs are widely shared is a measure of its strength. At one extreme, (see Figure 1) one may speak of a "strong" culture (in the strict sense) in which values and beliefs are widely shared across decision-making levels, functional units, and divisions. This would be synonymous with the idca of a single culture which is probably quite rare if not nonexistent in most organizations. At the other extreme is the weak culture in which valucs and beliefs differ across decision-making levels, functional units, and divisions. These values and beliefs will typically oppose one another, thereby producing a number 
of countercultures. Between these extremes, one may conceptualize the organization with a dominant set of core values (such as "innovation is our key competitive strength" or "customers come first") existing along with subcultures which may support or oppose the dominant culture values. Typically, a "strong culture" is identified as being one which falls towards the left on the continuum in Figure 1. Similarly, a "weak culture" would be one which falls towards the right in the same figure. In accordance with this, the terms "strong" and "weak" will be used throughout this paper to refer to the "loose definitions" in Figure 1.

\section{Figure 1}

Classification of Strong and Weak Cultures

$\underbrace{\begin{array}{c}\text { Strict Strong } \\ \begin{array}{c}\text { Culture } \\ \text { (Single Culture) } \\ \text { with Supporting, Neutral, or } \\ \text { Opposing Subcultures }\end{array}\end{array}}_{\begin{array}{c}\text { Range for loose definition } \\ \text { of strong culture }\end{array}} \begin{gathered}\begin{array}{c}\text { Strict Weak } \\ \text { Culture } \\ \text { (Countercultures) }\end{array} \\ \begin{array}{c}\text { Range for loose definition } \\ \text { of weak culture }\end{array}\end{gathered}$

\section{Outcomes Of Strong Cultures}

Those who argue that strong cultures are associated with positive performance outcomes $([8],[23])$ do so on the basis of two propositions. First, strong cultures provide day-to-day and strategic decision guidelines which clarify tasks and hence increase performance. Second, strong cultures instill feelings of belonging and identification with a particular organization, increasing commitment, and hence increasing performance.

\section{Figure 2}

Hypothesized Effects of a Strong Culture on Organizational Performance (Based on Deal and Kennedy [8] and Peters and Waterman [23])

\begin{tabular}{|c|c|c|c|c|c|}
\hline & Functions of Culture & \multicolumn{4}{|c|}{ Hypothesized Relationship to Performance } \\
\hline Proposition 1 & $\begin{array}{l}\text { Provision of Pathways } \\
\text { and Integration }\end{array}$ & $\stackrel{+}{\longrightarrow}$ & $\begin{array}{l}\text { Goal clarity } \\
\text { and } \\
\text { coordination }\end{array}$ & $\stackrel{+}{\longrightarrow}$ & $\begin{array}{c}\text { Individual and } \\
\text { Organizational } \\
\text { Performance }\end{array}$ \\
\hline Proposition 2 & $\begin{array}{l}\text { Support and } \\
\text { Identification }\end{array}$ & $\stackrel{+}{\longrightarrow}$ & $\begin{array}{l}\text { Organization } \\
\text { commitment }\end{array}$ & $\stackrel{+}{\longrightarrow}$ & $\begin{array}{c}\text { Individual and } \\
\text { Organizational } \\
\text { Performance }\end{array}$ \\
\hline
\end{tabular}

Perhaps the most forceful argument in favor of strong cultures is presented by Deal and Kennedy who argue that "the people who built the companies for which America 
is famous all worked obsessively to create strong cultures within their organizations" $([8]$, p. 8$)$. They attempt to support this in two ways (which are methodologically questionable). First, Deal and Kennedy cite an informal study anong McKinsey contsultants which concluded that from a sample of $80 \mathrm{firms}$, the 18 top performers all had strong cultures. Second, in order to follow up the initial evidence, they examined biographies of successful business leaders such as Thomas Watson (IBM), Will Durant (GM), William Kellogg (Kellogg's), and others. This led Deal and Kennedy to conclude that a unique characteristic of these leaders was their building of a strong culture within their firms. The specific influence of culture on performance is explained in two ways. First, they argue that "(a) strong culture is a system of rules that spelt exactly how people are to behave most of the time" ([8], p. 15). Second, a strong culture "enables people to feel better about what they do, so that they are more likely to work harder" ([8], p. 16).

The second major proponents of the link between strong culture and positive performance are Peters and Waterman [23]. They point out that all the "excellent" companies had a strong culture (i.e. Hands-On, Value-Driven). To quote:

Without exception, the dominance and coherence of culture proved to be an essential quality of the excellent companies. Moreover, the stronger the culture and the more it was directed toward the marketplace, the less need was there for policy manuals, organization charts, or detailed procedures and rules. In these companies, people way down the line know what they are supposed to do in most situations because the handful of guiding values is crystal clear. ([23], pp. 75-76)

Peters and Waterman also emphasize the "support and identification" role of culture, although indirectly. This is done primarily in their discussion of "Productivity Through People" (Chapter 8), where it is emphasized that excellent companies emphasize respect for the individual by viewing that individual as an integral part of the organization. This is evidenced by a number of practices such as full employment in times of recession, and referring to employees as "crew members" (McDonald's), "hosts" (Disney), and "associates" (J. C. Penney).

The hypothesized effects on organizational performance (Figure 2) are that through increasing goal clarity, coordination, and commitment, strong cultures function to enhance organizational performance. In light of research on goal setting, it may be argued that proposition 1 in Figure 2 is partially supported. For example, Latham and Baldes propose that "the setting of a goal which is both specific and challenging leads to an increase in performance because it makes clear to the individual what he is supposed to do" ([15], p. 173). However, the claim of "partially supported" is employed because culture provides only general guidelines.' Other writers such as Sathe [25], Schein [26], and Wilkins [35] have stated that this is a major function of culture.

The second proposition is questionable. There is some evidence that culture is connected to commitment [34] and that commitment leads to positive job outcomes 
such as effort, retention, attendance, job involvement [31], and turnover reduction [2]. But the assumption of a simplistic relationship between commitment and positive performance outcomes is seriously questionable [2].

In the next section, the extent to which the two propositions about strong cultures have affected thinking about the role which culture plays in the execution of day-today tasks in organizations is explored. In a subsequent section, the culture's role in strategic decision-making is addressed.

\section{Implications For Organization Theory and Strategy Implementation}

The two basic functions of culture articulated by Peters and Waterman [23] and Deal and Kennedy [8] were traditionally treated through concepts from the bureaucratic and human relations schools [22]. As summarized in Table 1, bureaucracy provided guidance through rules and procedures, task specialization, and an explicit hierarchy of authority [7]. Integration of activities took place through the use of task forces, teams, and committees [11]. The support and identification function was originally suggested by the human relations school [21] beginning with ideas developed from the Hawthorne study. The human relations model essentially argued that considerate leadership and allowing people to realize their higher order needs such as autonomy and self-actualization were all associated with higher performance levels.

Table 1

Traditional and Cultural Models

\begin{tabular}{|c|c|c|}
\hline & $\begin{array}{c}\text { Traditional } \\
\text { (Macro/Micro) }\end{array}$ & Cultural \\
\hline Direction & $\begin{array}{l}\text { Bureaucracy School - rules, } \\
\text { procedures; Leadership - } \\
\text { path goal; MBO - goal } \\
\text { setting; Motivation (PR) }\end{array}$ & $\begin{array}{l}\text { Company philosophy, } \\
\text { values, beliefs. }\end{array}$ \\
\hline $\begin{array}{l}\text { Support } \\
\text { and } \\
\text { Identification }\end{array}$ & $\begin{array}{l}\text { Human Relations, Human } \\
\text { Resources, Leadership, } \\
\text { Job Redesign }\end{array}$ & $\begin{array}{l}\text { Ceremonies, Stories, Heroes, } \\
\text { Recognition (e.g., "Salute } \\
\text { to the Stars" and "Pink } \\
\text { Cadillacs" at Mary Kay; } \\
\text { "Beer Busts" at Hewlett- } \\
\text { Packard }\end{array}$ \\
\hline
\end{tabular}

Today, guidance and control of employees is frequently based on a cybernetic model of some kind [13] where standards are set, accomplishment is measured and variance information is fed back to the participant. Drucker's [9] concept of management by objective (MBO) is a kind of cybernetic model, different only from the traditional in that those being "controlled" are allowed some participation in the standard setting process. Although the cybernetic models have limitations, according to Hofstede they seem to be widely used in management practice today. 
It seems then that up until the identification of culture as a management concept, the "guidance" and "support and identification" functions were carried on in organizations by managers who drew on concepts from the bureaucratic and luman relations schools, as well as other concepts such as $\mathrm{MBO}$. More recent refinements in human relations (the human resources or organizational behavior approaches) have developed a number of models in leadership $([10],[14])$ and motivation $([1],[16],[18])$ which have specifically addressed the handling of human resources.

Table 2

\section{Organizational Level}

\begin{tabular}{|c|c|c|}
\hline $\begin{array}{c}\text { Function of } \\
\text { Culture }\end{array}$ & Non-Managers & $\begin{array}{c}\text { Middle \& Upper Level } \\
\text { Managers }\end{array}$ \\
\hline \multirow[b]{2}{*}{$\begin{array}{l}\text { Pathways } \\
\& \\
\text { Integration }\end{array}$} & $\begin{array}{l}\text { Task Characteristics: } \\
\text { Simple, Routine }\end{array}$ & $\begin{array}{l}\text { Task Characteristics: } \\
\text { Complex, Changing }\end{array}$ \\
\hline & $\begin{array}{l}\text { Culture provides guid- } \\
\text { ance when surprises occur } \\
\text { that are not covered by } \\
\text { a rule or policy. Culture } \\
\text { reduces the need for up- } \\
\text { ward referral and tradi- } \\
\text { tional integration mecha- } \\
\text { nisms, such as task forces, } \\
\text { committees, and mutual } \\
\text { adjustment. }\end{array}$ & $\begin{array}{l}\text { Culture provides guide- } \\
\text { lines for coping with } \\
\text { continuous ambiguity. } \\
\text { Cultural control is more } \\
\text { rational under such con- } \\
\text { ditions than the tradi- } \\
\text { tional cybernetic control } \\
\text { mechanism. }\end{array}$ \\
\hline $\begin{array}{l}\text { Support } \\
\& \\
\text { Identification }\end{array}$ & $\begin{array}{l}\text { Where jobs possess few } \\
\text { intrinsically satisfying } \\
\text { features, culture may pro- } \\
\text { vide identification and } \\
\text { support through shared } \\
\text { ways of doing things } \\
\text { ("groupness"). This in- } \\
\text { creases understanding } \\
\text { for, and identification } \\
\text { with the whole } \\
\text { organization. }\end{array}$ & $\begin{array}{l}\text { Culture provides an } \\
\text { understanding of the } \\
\text { main purpose of the } \\
\text { organization and allevi- } \\
\text { ates managerial frustra- } \\
\text { tions through stories of } \\
\text { other similar problems } \\
\text { in the past. }\end{array}$ \\
\hline
\end{tabular}

${ }^{a}$ See Galbraith [11] for an exposition of these mechanisms.

${ }^{b}$ See Hofstede [13]. Hofstede argues that the cybernetic model is not appropriate for conditions where standards do not exist, accomplishment is not measurable, and feedback information cannot be used.

${ }^{c}$ Schein [26] argues that "( $t$ ) he process of culture formation is, in a sense, identical with the process of group formation in that the very essence of 'groupness' or group identity - the shared patterns of thought, belief, feelings, and values that result from shared experience and common learning - is what we ultimately end up calling the 'culture' of that group." (p. 50) 
A "strong culture" now seems to be offered as a "substitute" and "complement" to bureaucracy, leadership, and motivation. As shown in Table 2 culture may function as a substitute or complement at two organizational levels. For fairly simple and routine jobs characterized by specialization, social isolation, and little task significance, culture provides identification with the organization and in part substitutes for that which is lost in jobs with little prestige and autonomy. The culture allows the worker to identify with a larger more significant job. For example, at Mary Kay Cosmetics, beauty consultants (sales representatives) are made to feel that they are truly an important part of the company through ceremonies (The Salute to the Stars) and the general pomp and show that accompanies their tenure at the company [32]. Thus, in line with Hackman and Oldham's [12] Job Characteristic Model, culture has the potential for increasing the meaningfulness of work (albeit indirectly) by bringing the individual in touch with the organization and alerting him to its broader purpose. In essence then, where the organization cannot enrich the job, and hence contribute to pride in work, it attempts to appeal to a broader definition of pride - pride of working for that particular organization. Thus, culture to some degree "substitutes" for supportive leadership practices, especially where the task is not intrinsically satisfying or where the employee is socially isolated.

In higher level jobs where there is difficulty on clearly determining jobs and measuring performance, culture provides broad guidelines of what the executive needs to do to achieve success. As noted by Hofstede [13], cybernetic models do not work under such conditions.

\section{Strength Of Organizational Culture and Strategy Formulation}

Strategists have three basic roles. First, they must select from the repertoire of rational models (for example, PIMS, portfolio planning, environmental analysis, and Porter's industrial analysis framework) those which enable the organization to identify external opportunities and threats. Second, they must convince their colleagues that this more time-consuming approach is justified by (1) the complexity of the problem at hand, and (2) the potential payoffs of a more accurate decision. Third, they must convince those involved in implementation to go along with the recommendations coming out of the formal plan.

At this point, strategic decision makers face the problem of overcoming precedents set by the prevailing culture (akin to Starbuck's [30] "behavior programs"). This culture has (broadly and non-specifically) laid down guidelines for completing both strategic and day-to-day tasks. The culture implicitly tells decision-makers which markets the firm traditionally competes in and how it interacts with its various stakeholders. Where strategic decision-makers perceive the need for radical change, they are unlikely to be supported when the firm has experienced past success with an established strategy. For example, in John DeLorean's account of events at General Motors, he describes the rationale for automobile design and building: "( $m$ )ore than one car was built and designed a certain way because a top executive thought it was 
a nice car, despite numerous marketing analyses that dictated a different approach" ([36], p. 149).

In attempting to explain why this mode of decision-making was so prevalent at GM, DeI,orean continues, "(f)or the most part, a top executive by the time he works his way through the system is a carbon copy of his predecessors. If the men in place cannot do the job, there is no reason to believe that their hand-picked successors can. There never was, in most of my days with General Motors, an at tempt to analyze previous corporate decisions to see if they were right for the company, and to use this information in perfecting the management process of the future" $([36]$, p. 215 , emphasis added).

It should be emphasized that DeLorean spoke of a mode of decision-making which had strategic implications for the firm. In Business Week's later accounts of GM's response to the fall in gasoline prices in the early 1980 s, it seems that this mode was still in place.

Why didn't GM respond? One explanation: Executives became more intent on carrying out the program than in asking whether it made sense. "The presumption was that whatever we were doing was very, very, good," recalls Gerald P. Hirschberg, a former chief designer for Pontiac, and Buick who is now director of design for Nissan Design International lnc. in San Diego. The company was full of executives, including designers, who only had to keep things going. The muscles of creativity atrophied. ([4], p. 105)

In many organizations, decision-makers resist changes in the interest of preserving the well-being of the organization and hence their own survival, even if the decisions made are misguided. This resistance is not irrational, but instcad reflects a different belief about how strategies should be developed. In reality, most derision-makers depend on both analytical and traditional/cultural guidelines. However, the cultural guidelines are usually less costly in the short term, and not as intellectually exhaust. ing. In many ways, the culture acts as a mechanism of "programming" the decision process in a manner similar to programming via rules. The major difference is in the breadth of the guidelines rather than its overall results. In this manner, culture places a limit on the number of alternatives to be considered when a problem is encountered. The decision-maker will then choose the most readily available alternative within the mix of potential solutions. Very frequently, unless the firm is faced with severe external conditions which challenge its very existence, the array of decisions considered will not move toward a more exhaustive analysis of the forms internal and external situation. In addition, if an exhaustive analytical process challenges the current strategy or suggests major internal changes, the decision-maker may allow cultural norms to override and influence in the organization.

The proponents of analytical approaches to strategy formulation attempt to "sell" it through supporting evidence that it allows the firm to achieve higher performance levels $([5],[24],[27])$. Nevertheless, analytical decisions in organizations are constrained by the "conventional wisdom" which is frequently disseminated through a system of 
storics, legends, and ceremonies in addition to other formal control mechanisms such as rules, procedures, and reward systems. This "conventional wisdom" will remain in place despite smäll challenges to its viability. Until an adequately severe challenge is faced which threatens the existence of the firm (for example, those introduced by Japanese firms to the automobile and electronics industries), the "conventionai wisdom" will remain intact. Recent challenges to U.S. management practices by Japanese firms, especially in areas of product quality and handling of human resources, have been this sort of adequately severe challenge. Only where a superior practice was identified which translated into a competitive advantage did companies react and look inward with the hope of modifying these practices.

The preceding discussion has shown that culture is important in the strategy process. But under what conditions are strong or weak cultures appropriate?

\section{Conditions Fuvoring Strong Or Weak Cultures}

The position that strong cultures are always better than weak ones may be rejected. While culture cannot be "managed," the CEO will influence the direction which cultural development takes. The CEO must recognize the tradeoff of cohesiveness and direction provided by a strong culture, with the inability to change easily in response to new opportunities. Some will argue that strong cultures, emphasizing innovation and change, do not present difficullies to the firm where major change is needed. But this argument can be misleading. Many firms with these "innovative" cultures will resist change to bring about a more mechanistic and efficiency-oriented system as required in pursuing a cost leadership strategy. The reasoning is simple. Those comfortable with the ambiguity and challenge of an innovative or flexible culture will probrably not find a more routine and mechanistic environment to their liking.

Strong cultures are appropriate if they allow the firm to focus on the "right" things, irrespective of whether the firm is operating under stable or turbulent conditions. Thus, the strong culture which specifies the manner of environmental linkage (i.e., the customer comes first) or certain internal practices which allow the firm to be successful in its industry (i.e., "innovation is important," "failure is tolerated") will be a better performer to the extent that the culture emphasizes a critical success factor.

A strong culture is also appropriate to the extent that it emphasizes true diversity in approaches to problems. This is not easily attained in practice as many growing and "innovative culture" firms may resist becoming more mechanistic as this could entail the loss of some freedoms associated with a looser structure. At any transition point in the life of a firm, it is primarily the CEO's role to anticipate change and prepare the firm for this transition.

Weak cultures are appropriate in stable or turbulent environments if firms in that industry are young, and if no superior methods of doing things have been established. Firms at this stage are experimenting and the culture is slowly beginning to develop. Usually, a weak culture in a stable environment is acceptable in the short run, but it must soon move towards being strong. In a turbulent environment, weak cultures 
are often found in young firms and at transition points. To the extent that a mismatch between the firm and its environment exists, the prevailing culture may weaken somewhat as transitions occur. At this point, the CEO is either instrumental in such changes, or a new CEO with different views has taken over. Table 3 summarizes these points.

Table 3

\section{Appropriate Conditions for Strong and Weak Cultures}

\begin{tabular}{|c|c|c|}
\hline & \multicolumn{2}{|c|}{ Environment } \\
\hline & Stable & Turbulent \\
\hline $\begin{array}{l}\text { "Strong } \\
\text { Culture" }\end{array}$ & $\begin{array}{l}\text { Appropriate if allows firm to } \\
\text { focus on critical issues. } \\
\uparrow\end{array}$ & $\begin{array}{l}\text { Appropriate if allows true } \\
\text { flexibility. Usually better in } \\
\text { smaller firns. }\end{array}$ \\
\hline $\begin{array}{l}\text { "Weak } \\
\text { Culture" }\end{array}$ & $\begin{array}{l}\text { desired | movement } \\
\text { Appropriate in short-run only } \\
\text { where technologies are evolving. }\end{array}$ & $\begin{array}{l}\text { Appropriate as firm goes through } \\
\text { transition, or where a young firm } \\
\text { is trying to find new ways of } \\
\text { approaching its industry. }\end{array}$ \\
\hline
\end{tabular}

Summary, Conclusions, and Research Questions

While a strong culture has positive outcomes with administrative tasks through the provision of direction and support, it generally may not have positive consequences in turbulent environments where rapid strategic change is needed. To the extent that the culture does emphasize true flexibility and openness, the firm may adapt well to environmental demands. But the possession of an "innovative culture" alone is not enough. Events at Apple Computer, necessitating a change toward a different kind of structure, required the influence of a new executive. Strong cultures are typically best where they focus the firm's energies on critical success factors and, at the same time, provide room for generating and implementing new ideas. This situation is similar to "moderately strong cultures" which consist of dominant core values with supporting, neutral, or opposing subcultures.

Weak cultures exist in young firms and are appropriate where the firm needs to find new ways of doing things. As the firm gains an understanding of its environment and industry, its values and beliefs begin to strengthen and provide overall guidance to the firm. In stable environments, weak cultures may be appropriate in the short term, but as an understanding of the firm's environment develops and its cultures become stronger, the firm will realize the benefits of a strong culture. Weak cultures are primarily useful in facilitating transitions whereas strong cultures will inhibit them.

In concluding, three major research questions are suggested. First, do strong cultures, foster commitment and individual performance as proposed in Figure 2? Second, how can firms diagnose and change their cultures in order to more appropriately match environmental conditions? Finally, how can strategic managers overcome 
values and beliefs that fundamentally undermine the competitive advantage of the firm?

\section{References}

1. Adams, J. S. "Inequality in Social Exchange." In L. Berkowitz (ed.), Advances in Experimental Social Psychology, Vol. 2, pp. 267-299. New York, NY: Academic Press (1965).

2. Angle, H. L. and Perry, J. L. "An Empirical Assessment of Organizational Commitment and Organizational Effectiveness." Administrative Science Quarterly, Vol. 26 (1981), pp. 1-14.

3. Barney, J. B. "Organizational Culture: Can it be a Source of Sustained Competitive Advantage?" Academy of Management Review, Vol. 11 (1986), pp. 656-665.

4. Business Week. "General Motors: What Went Wrong?" March 16, 1987.

5. Camerer, C. "Redirecting Research in Business Policy and Strategy." Strategic Management Journal, Vol. 6 (1985), pp. 1-15.

6. Chace, S. "The Corporate Culture at IBM: How It Reinforces Strategy." In A. A. Thompson, A. J. Strickland, and W. E. Fulmer (eds.), Readings in Strategic Management. Plano, TX: Business Publications Inc. (1984).

7. Daft, R. L. Organization Theory and Design, 2nd Edition. St. Paul, MN: West Publishing Company (1986).

8. Deal, T. E. and A. A. Kennedy. Corporate Cultures: The Rites and Rituals of Corporate Life. Reading, MA: Addison-Wesley (1982).

9. Drucker, P. F. The Practice of Management. London, England: Pan Books. (1968; first edition 1955).

10. Fiedler, F. E. A Theory of Leadership Effectiveness. New York, NY: McGrawHill (1967).

11. Galbraith, J. R. "Matrix Organization Designs." Business Horizons, Vol. 14 (1971), pp. 29-40.

12. Hackman, J. R. and G. R. Oldham. Work Redesign. Reading, MA: AddisonWesley (1980).

13. Hofstede, G. "The Poverty of Management Control Philosophy." Academy of Management Review, (1978), 450-461.

14. House, R. J. and T. R. Mitchell. "A Path Goal Theory of Leadership." Journal of Contemporary Business, Vol. 3 (1974), pp. 81-99. 
15. Latham, G. P. and J. J. Baldes. "The "Practical Significance" of Locke's Theory of Goal Setting." Journal of Applied Psychology, Vol. 60, (1975), pp. 122-124.

16. Luthans, F. and R. Kreitner. Organizational Behavior Modification. Glenview, IL: Scott, Foresman and Company (1975).

17. Martin, J. and C. Siehl. "Organizational Culture and Counterculture: An Uneasy Symbiosis." Organizational Dynamics, (Autumn, 1983), pp. 52-64.

18. Mitchell, T. R. and L. R. Beach. "A Review of Occupational Preference and Choice Research Using Expectancy Theory and Decision Theory." Journal of Occupational Psychology, Vol. 99 (1976), pp. 231-248.

19. Ouchi, W. G. Theory Z: How American Business Can Meet the Japanese Challenge. Reading, MA: Addison-Wesley (1981).

20. Pascale, R. "Fitting New Employees into the Company Culture." Fortune, Vol. 109 (1984), pp. 28-43.

21. Perrow, C. Complex Organizations: A Critical Essay, 3rd Edition. New York, NY: Random House (1986).

22. Perrow, C. "The Short and Glorious History of Organization Theory." Organizational Dynamics, (Summer, 1973).

23. Peters, T. J. and R. H. Waterman. In Search of Excellence: Lessons from America's Best-Run Companies. New York, NY: Harper and Row (1982).

24. Porter, M. F. Competitive Advantage. New York, NY: Free Press (1985).

25. Sathe, V. Culture and Related Corporate Realities. Homewood, IL: Richard D. Irwin (1985).

26. Schein, E. H. Organizational Culture Leadership. San Francisco, CA: JosseyBass (1985).

27. Schoeffler, S., R. D. Buzzell, and D. F. Heany. "Impact of Strategic Planning on Profit Performance." Harvard Business Review (March-April, 1974).

28. Schwartz, H. and S. M. Davis. "Matching Corporate Culture and Business Strategy." Organizational Dynamics (Summer, 1981), pp. 30-48.

29. Siehl, C. and J. Martin. "The Role of Symbolic Management: How Can Managers Effectively 'Transmit Organizational Culture?" In J. G. Hunt, D. Hosking, C. A. Schriesheim, and R. Stewart (eds.), Leaders and Managers, New York: Pergamon (1984).

30. Starbuck, W. H. "Organizations as Action Generators." American Sociological Review, Vol. 48 (1983), pp. 91-102. 
31. Steers, R. M. "Antecendents and Outcomes of Commitment." Administrative Sciences Quarterly, Vol. 22 (1977), pp. 45-56.

32. Thompson, A. A. and A. J. Strickland. Strategic Management: Conccpts and Cases, 4th Edition. Plano, TX: Business Publications, Inc. (1987).

33. Trice, H. M. and J. M. Beyer. "Studying Organizational Cultures Through Rites and Ceremonial." Academy of Management Review, Vol. 9 (1984), pp. 653-669.

34. Wiener, Y. "Commitment in Organizations: A Normative View." Academy of Management Review, Vol. 7 (1982), pp. 418-428.

35. Wilkins, A. L. "The Cultural Audit: A Tool For Understanding Organizations." Organizational Dynamics (Autumn, 1983), pp. 24-38.

36. Wright, J. P. On a Clear Day You Can See General Motors. Grosse Point, MI: Wright Enterprises (1979). 